\title{
Internal Structure of Large Size Vacuum-Cast Ingots
}

\author{
By Shinsaku Onodera**, Yoshitaka Nakagawa*** \\ and Noboru Hiraoka****
}

\section{Synopsis}

In spite of a number of papers on the utility of vacuum ingot casting, it seems that the reason has not been sufficiently traced back to the improvement in the nature of ingot thus obtained.

In the present paper three vacuum-cast forging ingots $9 \mathrm{t}$, $25 \mathrm{t}$ and $75 \mathrm{t}$ ) were examined and compared with an air-cast ingot $(75 \mathrm{t})$. The results of the investigation revealed some characteristics inside the large vacuum-cast ingots. They are as follows:

(1) Gases and oxide inclusions are decreased notably, and thus the opinions of the published papers are reconfirmed.

(2) The V-segregation is reduced and nearly absent in ingots of $25 \mathrm{t}$ and smaller. The inverse- $\mathrm{V}$ segregation is dispersed and improved. (Examined by sulphur print and macroetching.

(3) Cavities and loose structures are remarkably reduced and especially compactness of the inverse- $\mathrm{V}$ string zone is improved.

(4) Distribution of chemical compositions throughout the vacuum-cast ingots is more uniform.

These features demonstrate the superior quality of vacuumcast steels, with particular reference to the results of ultrasonic testing and bore inspections of rotors.

\section{Introduction}

Since June, 1959, when the vacuum-casting facilities for large forging ingots started operations, more than 28,000 tons of these new ingots ranging from 10 to $220 \mathrm{t}$ each have been manufactured at the Muroran Plant of the Japan Steel Works, Ltd. The quality of the heavy forgings produced from these ingots is showing magnificent amelioration such as the improvement in the rejection rate, reduction of process time and prevention of delay in the delivery period. Such improvements are particularly remarkable in heavy rotors for turbines and generators satisfying the requirement that their sections should be thoroughly sound to the core zone. The authors believe, it is a contribution to the rapidly increasing demand for power generation in Japan.

It has been widely established that the utility of vacuum ingot making is primarily evident in large ingots or forgings obtained therefrom ${ }^{1)}$. But the reason for the progress apparently has not been sufficiently investigated. The improvements due to this new technique have been judged statistically in recent years along with the flow of completed products by the use of some non-destructive testings such as ultrasonic flaw detection for inspection of the inner quality. Strictly speaking, however, the reason must be traced back to the origins directly correlated either to the ingot, to the forging process or to the history of its thermal treatments in respective stages.

It is most evident that the changes in the internal structure of the ingot should play a leading role herein, but there have been very few reports, to the authors' knowledges, which stated definitely how the vacuum-cast ingot changed and was improved in internal quality. This presumably could be attributed to the following common suppositions:

i) Comparative investigations of two ingots which have been cast in two identical moulds from the same heat, one in air and the other in vacuo, may have some drawbacks for large size products, because the proposed improvements in internal structure due to vacuum casting might not be evident enough to warrant the cost and time involved.

ii) There still are many ambiguities in the process of solidification and segregation, and it is probably almost impossible to reproduce ingots of identical inner properties. Thus the effects of vacuum casting can not be judged unless considerable numbers of comparative studies are conducted.

Recently the authors have published the results of investigation with two air-cast ingots (75 t and $25 \mathrm{t}$ ) which demonstrated some of their new techniques and findings in the study of large-sized ingots. Upon examining three of the vacuum-cast ingots, and comparing the results with the findings of the above air-cast ingots inspections, several characteristic features of vacuum-cast ingots have been found.

\section{Test Ingots}

The ingots tested are concave-octagonal of $9 \mathrm{t}$, $25 \mathrm{t}(0.34 \%$ carbon steels, melted in a basic arc furnace) and 75 t ( $3 \%$ Ni-Mo-V steel, melted in an open hearth furnace) weight. Each was cast in vacuo in a pre-evacuated tank. Then the tank was reverted to atmospheric pressure by introducing nitrogen and a strong electric heating was applied to the hot top until solidification was completed. Chemical compositions, pouring temperature and vacuum degree of casting are shown in Table 1. The 9-t and 25-t ingots were cut into pieces immediately after cooling to room temperature, while the 75-t ingot was cut after annealing, and all were submitted to examinations.

\section{Methods of Sampling, Analyses and Ex- aminations}

\section{Preparation of Samples}

Fig. 1 shows the size of tested ingots and plan

* Lecture delivered before the 61st Grand Lecture Meeting of the Iron \& Steel Institute of Japan on April 4, 1961 in Tokyo. Japanese text was printed in "Tetsu-to-Hagané" (Journal, Iron \& Steel Institute, Japan) Vol. 47, No. 3, pp. 383-384.

** Dr. Eng., Research Centre, Muroran Plant of the Japan Steel Works, Ltd.

*** Dr. Sci., the same centre.

***** Engineer, the same centre. 
Table 1. Ladle analysis and pouring conditions for tested ingots

\begin{tabular}{|c|c|c|c|c|c|c|c|c|c|c|c|c|}
\hline \multirow{2}{*}{$\begin{array}{c}\text { Ingots } \\
\text { (t) }\end{array}$} & \multicolumn{10}{|c|}{ Chemical compositions $(\%)$} & \multicolumn{2}{|c|}{ Pouring conditions } \\
\hline & $\mathrm{C}$ & $\mathrm{Si}$ & $\mathrm{Mn}$ & $\mathrm{P}$ & $\mathrm{S}$ & $\mathrm{Ni}$ & $\mathrm{Cr}$ & $\mathrm{Cu}$ & Mo & $\mathrm{V}$ & $\begin{array}{l}\text { Vacuum } \\
\text { (Torr) }\end{array}$ & $\begin{array}{c}\text { Temperature } \\
\left({ }^{\circ} \mathrm{C}\right)\end{array}$ \\
\hline 9 & 0.34 & 0.34 & 0.58 & 0.015 & 0.010 & 0.09 & 0.10 & 0.13 & 0.02 & - & $4 \sim 8$ & $1570^{*}$ \\
\hline 25 & 0.34 & 0.27 & 0.52 & 0.012 & 0.011 & 0.08 & 0.11 & 0.14 & 0.02 & - & $5 \sim 8$ & $1570^{*}$ \\
\hline 75 & 0.32 & 0.30 & 0.54 & 0.013 & 0.018 & 3.00 & 0.14 & 0.07 & 0.41 & 0.06 & $4 \sim 5$ & $1570^{*}$ \\
\hline
\end{tabular}

* Designed for pony ladle value.

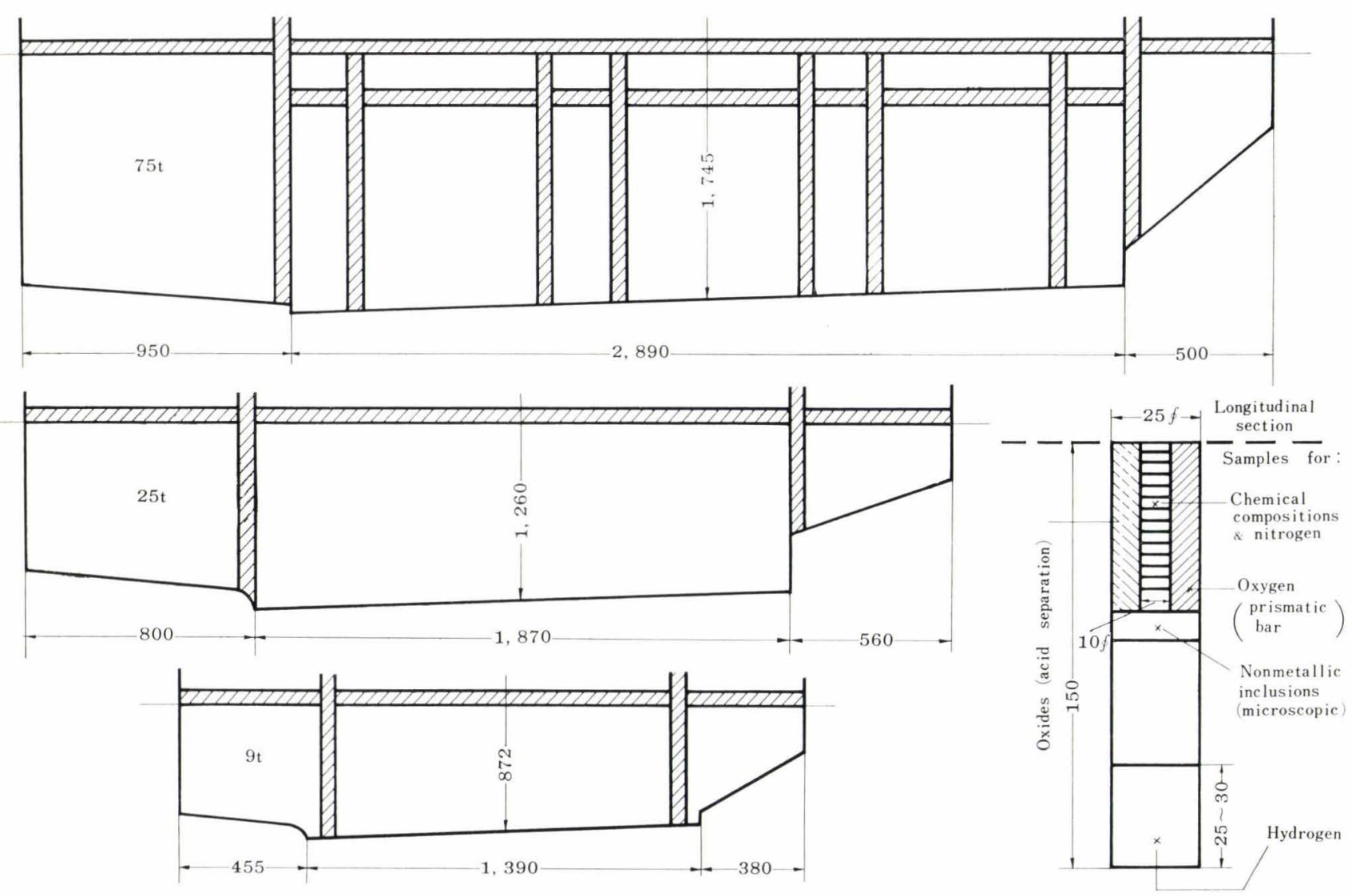

Fig. 1. Size of tested ingots including the plan of cutting and sampling

of cutting, including the sampling for analysis. The analytical samples were taken out, as they were water-cooled, by a core-drilling machine perpendicularly to the longitudinal section passing the axis with particular caution taken with the deepest portions so that the samples might not exceed room temperature. As seen in Fig. 1, the hydrogen samples are located at least $120 \mathrm{~mm}$ deep from the longitudinal section, so the evolution of hydrogen from the hydrogen samples before their separation from the bulk of ingot would be negligible even if the longitudinal section were left at room temperature for three months or more. The sampling was completed within one month and half after longitudinal cutting-off.

\section{Method of Examination and Analysis}

i. Macro-Examination

Both longitudinal and transverse sections were examined by means of sulphur print and macroetching (primarily by the cupric ammoneous chloride method), and the defective structures found on the respective sections were photographed in natural size and in 5.2 magnifications before and after macro-etching.

ii. Analyses of Chemical Compositions and Nitrogen

C, Si, Mn, P, S and other chemical compositions and nitrogen were analyzed according to the Japan Industrial Standard (JIS) method, 
iii. Analyses of Oxygen, Hydrogen and Oxide Inclusions

Oxygen was analyzed by the vacuum fusion method, hydrogen by vacuum extraction method at $950^{\circ} \mathrm{C}$, and oxide inclusions by a warm nitric acid separation method.

\section{iv. Microscopic Nonmetallic Inclusions}

Nonmetallic inclusions were measured with a microscope at 100 magnifications by comparison of the total area of inclusions to the total field of vision according to the third process of Determination of Nonmetallic Inclusions specified by Japan Society for the Promotion of Science.

\section{Results of Testing and Observations}

\section{Nature of Longitudinal Section of Ingots}

i. Sulphur Print and Macro-Etching

Fig. 2 shows the sulphur print of 9-t and 25-t ingots. Fig. 3 shows the sulphur print of 75 -t ingot compared with that of an air-cast ingot which has nearly the same weight and slightly different shape.

Based on these two figures and the results of other observations it can be stated that the vacuumcast ingots have some definite features, as follows.

a) The V-segregation is reduced largely in

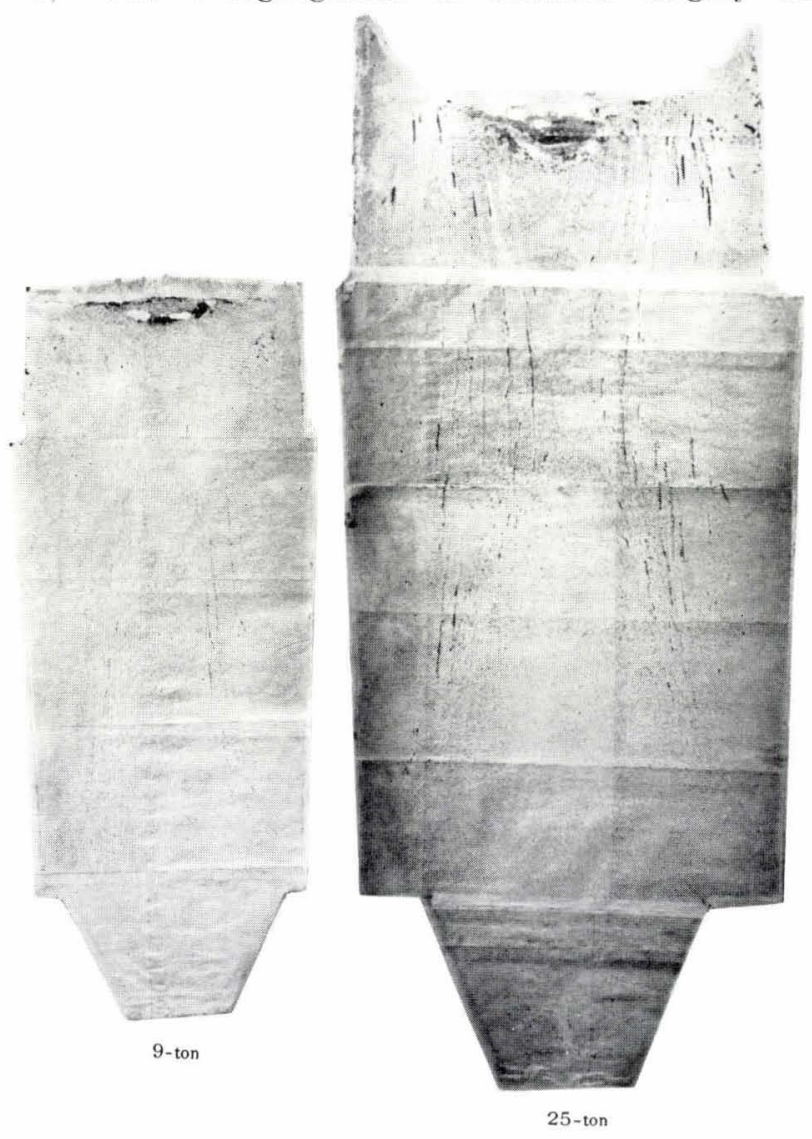

Fig. 2. Sulphur print of 9-ton and 25-ton ingots vacuum-cast ingots. As obviously seen in Fig. 2, $\mathrm{V}$-segregation seems apparently to cease to exist in the vacuum-cast ingot of 25 tons and smaller. In the 75-t ingot it remains to some extent, but the degree is much less than that of air-cast ingot. This is also confirmed by many cases of highpressure cylinders of which hot-punched cores in their longitudinal sections were studied in comparison with air-cast and the vacuum-cast products.

b) Inverse- $\mathrm{V}$ segregation extends itself in a wider range, i.e. from the bottom of a ingot body up to the feeder of the ingot axially and from just inside of the columnar zone nearly to the core portion radially. But each individual string of the inverse- $V$ segregates, as is observed in the transverse section of the vacuum-cast ingots, becomes more compact as a whole and more dense in their periphery as compared with the air-cast ingots.

c) The intermediate segregated zone between the $\mathrm{V}$ - and inverse- $\mathrm{V}$ segregations observed in aircast ingots practically disappears in the vacuumcast ingots.

d) The depth of columnar zone shows no change. The macrostructure inside this zone apparently shows no remarkable change.

The above comparative observation may not be
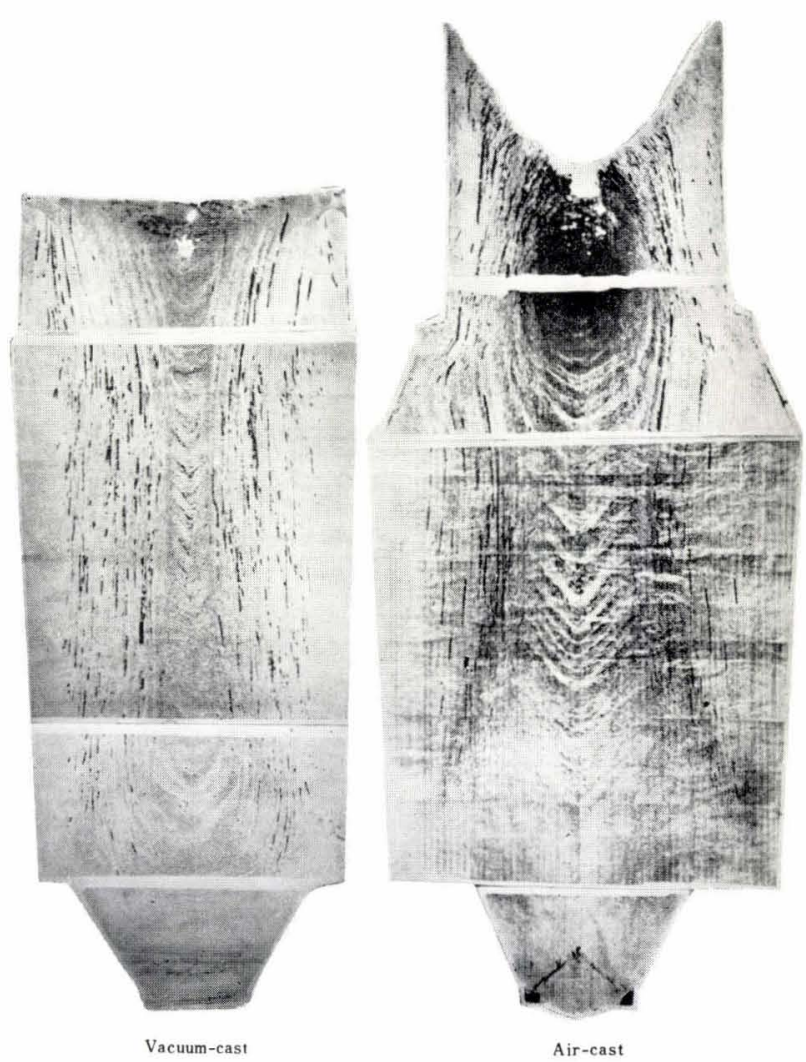

Fig. 3. Sulphur print of 75-ton ingots, vacuum-cast and air-cast 
true in a strict sense, because the shape of ingots, temperature and rate of pouring and thermal insulation of the feeder head have some additional effects upon the merits of vacuum casting. Nevertheless the improvement is decisive beyond these differences in conditions.

\section{ii. Defects of Internal Structure of Ingots}

According to the inspection of longitudinal sections in as-polished or after macro-etched states, the cavities and loose structure ordinarily accompanied by segregated zones or strings in air-cast ingots are remarkably diminished.

In the 9-t and 25-t ingots examined, only a few cavities of $1 \mathrm{~mm}$ diameter or less were observed. Apparently deffects in the ordinary sense are scarce in the ingots. The 75-t ingot tested showed a considerable number of defects primarily in the zone of $\mathrm{V}$-segregates. By comparing the representative examples of defects to those of air-cast ingots as in Fig. 4, however, definite amelioration is also shown. The specific features are as follows:

a) The cavities accompanied by the V-and inverse- $V$ segregations are reduced in size and number in the vacuum-cast ingots and are not continuously distributed as in the case of air-cast ingots.

b) The cavities accompanied by the V- and inverse- $V$ segregates, appear in lesser degree along the V-segregation.

c) The most noticeable point is that the contour of the inverse- $\mathrm{V}$ strings has not been deeply carved by macro-etching, and that the inverse-V strings contain in themselves no locally etched pits. This shows an improvement in inverse- $V$ strings and associated structure therewith.

iii. Amelioration of Internal Structure of Ingots So far, it is confirmed that, in the vacuum-cast

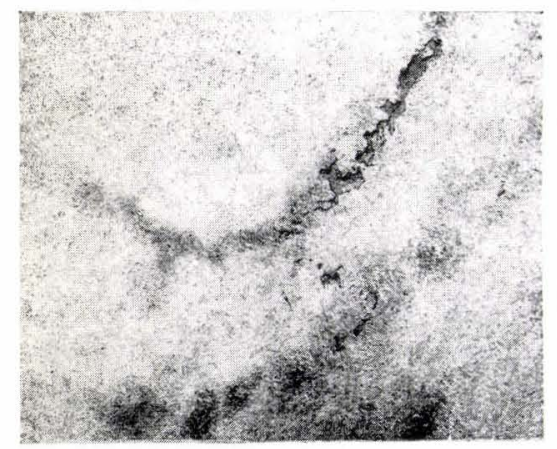

V-segregation $(\times 1.1 \times 3 / 5$

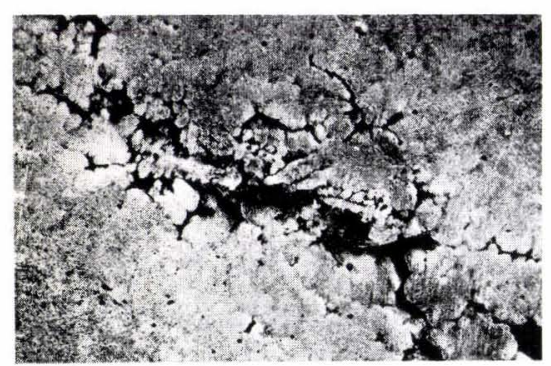

V-segregation $(\times 5.2 \times 3 / 5$

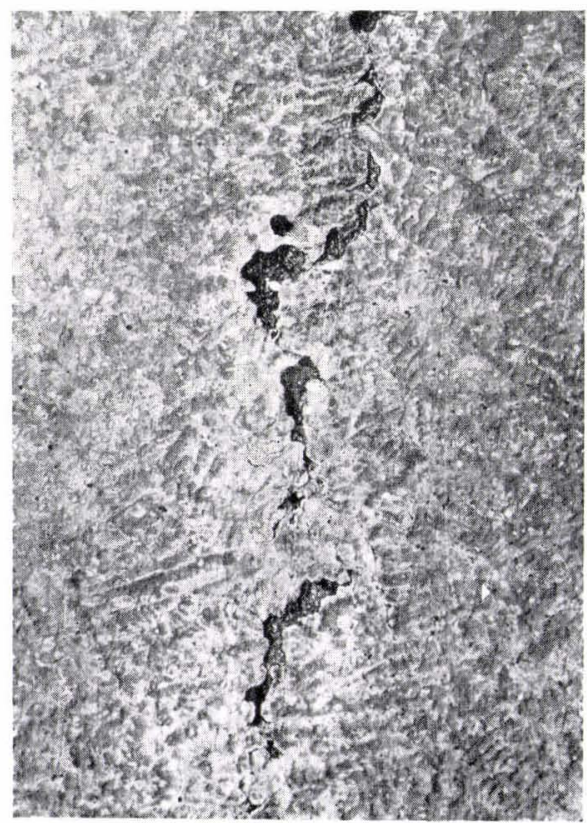

Inverse- $\mathrm{V}$ segregation $(\times 5.2 \times 3 / 5$

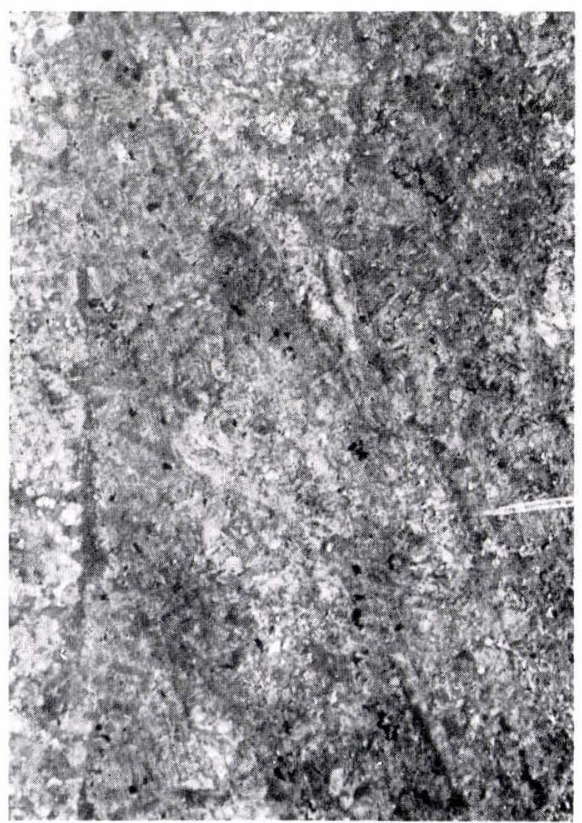

Inverse-V segregation $(\times 5.2 \times 3 / 5$

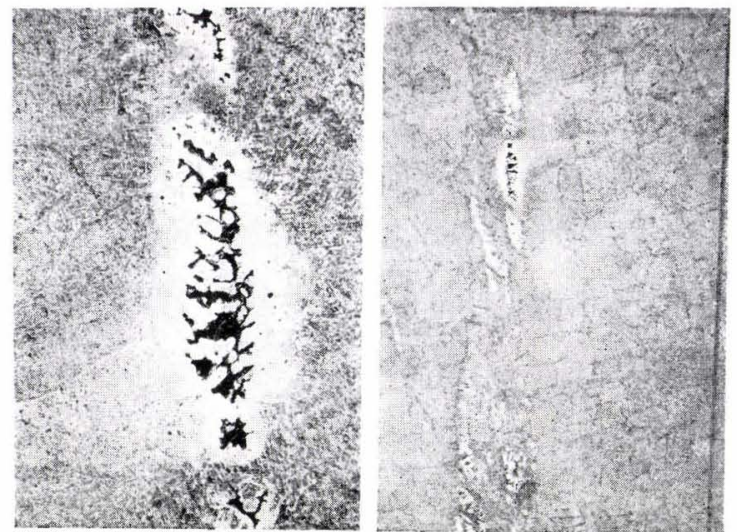

Inverse-V segregation $(\times 5.2 \times 3 / 5)$ Inverse- $\mathrm{V}$ segregation $(\times 1.1 \times 3 / 5$
Fig. 4. Examples of defects accompanied by segregation in 75-ton ingots (upper : vacuum-cast, lower : air-cast) 
ingots, the V-segregation is reduced largely and the inverse- $V$ segregation is dispersed and improved, while cavities and loose structures are remarkably improved, resulting in a better compactness of inverse-V segregates. The so-called "ghost line" has not been in itself any defect of the ingot or forging, but the defects coexisting with the ghost zone have to be, as is generally recognized, blamed. Based on the findings that the zones of inverse- $V$ and V-segregations increase in soundness in vacu-
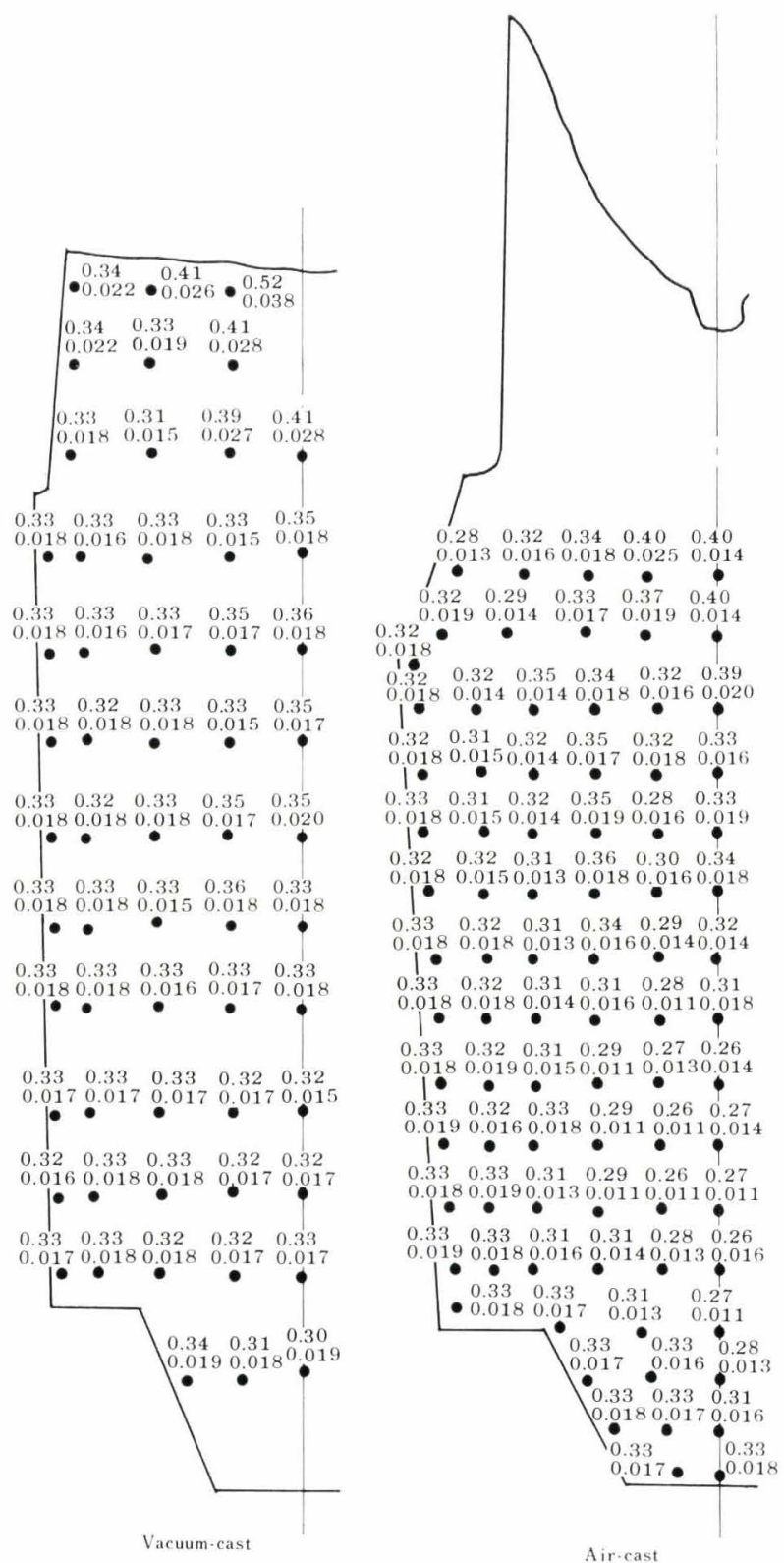

Fig. 5. Distribution of $\mathrm{C}$ and $\mathrm{S}$ in 75-ton ingots (figures show-upper : C, lower : S) um-cast ingots, the dispersion of inverse-V segregates has no harmful effects on the forging quality. In fact, large rotors made from these improved ingots have shown better results than ever in both core hole inspection and ultrasonic tests.

\section{Segregation of Chemical Elements}

In succession to qualitative observation of the macro-segregation, a segregation determined by the mean analyses of $25 \mathrm{~mm}$ dia. samples (Fig. 1) is
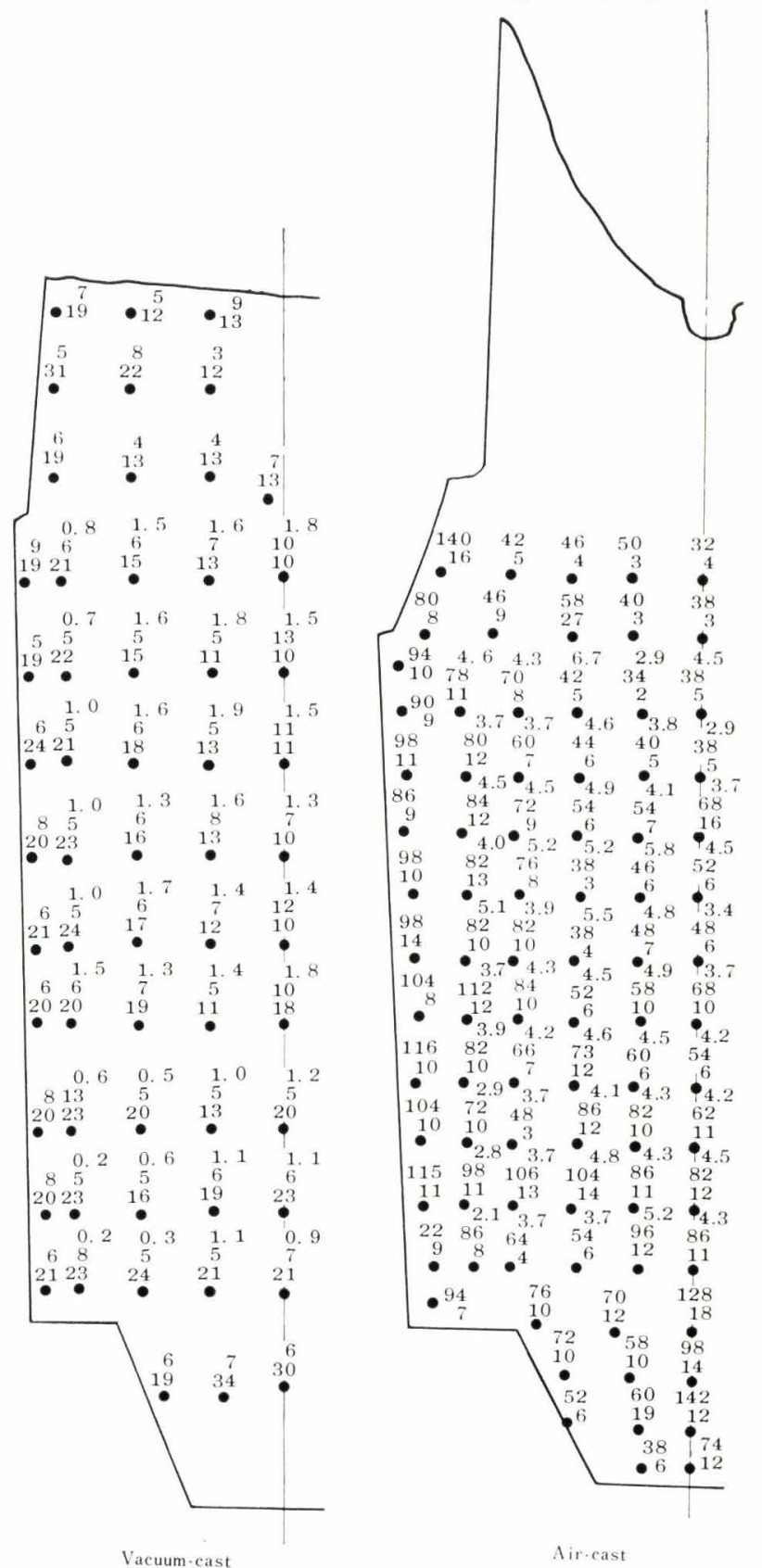

Fig. 6. Distribution of $\mathrm{H}_{2}, \mathrm{SiO}_{2}$ and $\mathrm{Al}_{2} \mathrm{O}_{3}$ in 75-ton ingots (Figures show from top to bottom $\mathrm{H}_{2}$, $\mathrm{SiO}_{2}$ and $\mathrm{Al}_{2} \mathrm{O}_{3}$, except feeder head and foot where only $\mathrm{SiO}_{2}$ and $\mathrm{Al}_{2} \mathrm{O}_{3}$ are indicated.) 
Table 2. Distribution of $\mathrm{Si}, \mathrm{Mn}, \mathrm{P}$ and $\mathrm{Ni}$ in 75-ton ingots As for the positions of sampling refer to Fig. 5.

$$
\text { (\%) Vacuum-cast ingot }
$$

Air-cast ingot

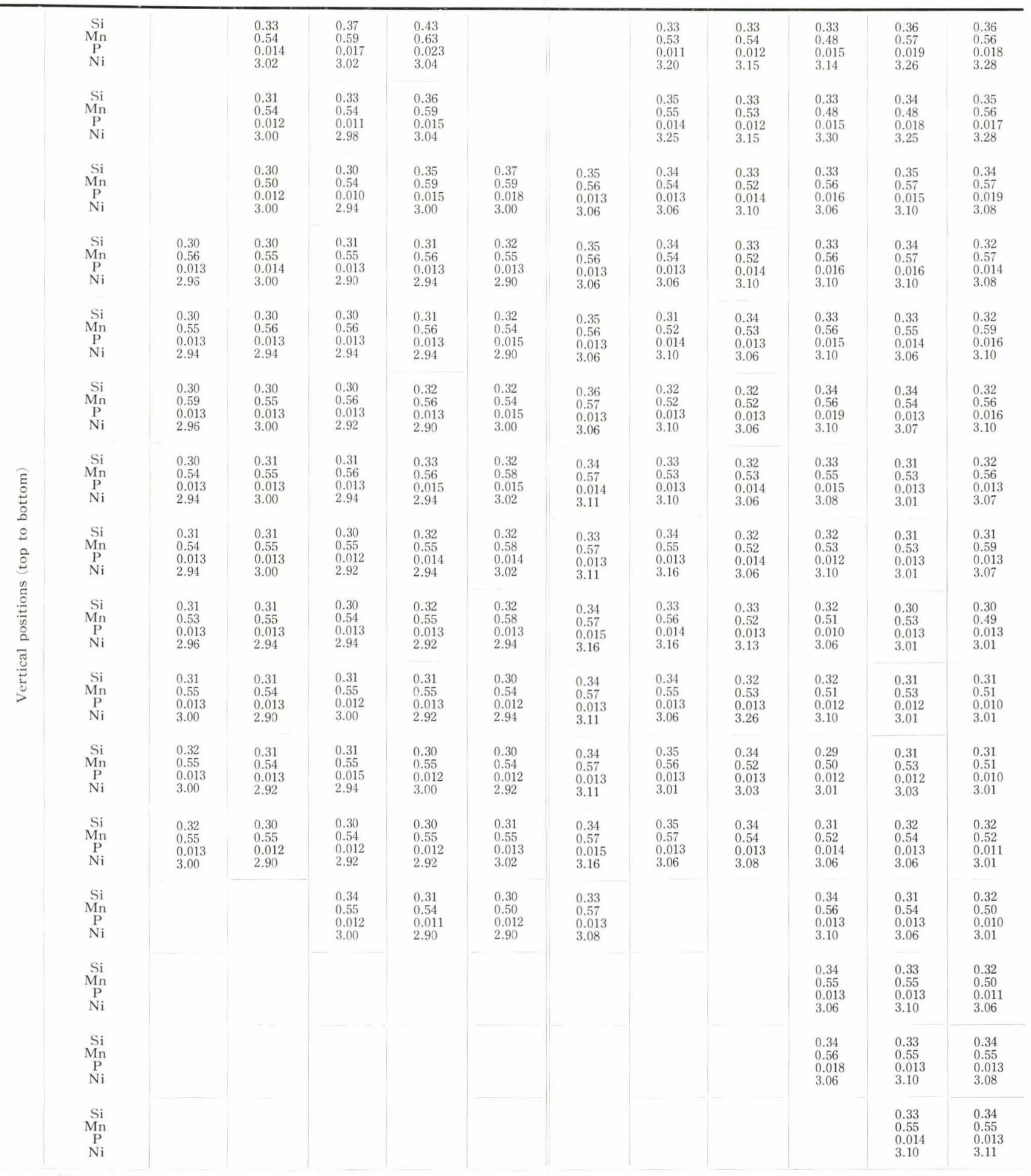


Table 3. Distribution of $\mathrm{Cr}, \mathrm{Mo}, \mathrm{V}$ and $\mathrm{Al}$ in 75 -ton ingots

(As for the position of sampling refer to Fig 5.

Elements

Radial positions (periphery to center)

(\%)

Vacuum-cast ingot

Air-cast ingot

\begin{tabular}{|c|c|c|c|c|c|c|c|c|c|c|c|c|}
\hline & $\begin{array}{c}\mathrm{Cr} \\
\mathrm{M} / \\
\mathrm{V} \\
\mathrm{Al}\end{array}$ & & $\begin{array}{l}0.13 \\
0.41 \\
0.09 \\
0.007\end{array}$ & $\begin{array}{l}0.11 \\
0.44 \\
0.09 \\
0.005\end{array}$ & $\begin{array}{l}0.13 \\
0.51 \\
0.12 \\
0.005\end{array}$ & & & $\begin{array}{l}0.12 \\
0.27 \\
0.09\end{array}$ & $\begin{array}{l}0.10 \\
0.40 \\
0.09\end{array}$ & $\begin{array}{l}0.10 \\
0.39 \\
0.09\end{array}$ & $\begin{array}{l}0.11 \\
0.44 \\
0.09\end{array}$ & $\begin{array}{l}0.10 \\
0.45 \\
0.09\end{array}$ \\
\hline & $\begin{array}{c}\mathrm{Cr} \\
\mathrm{Mo} \\
\mathrm{V} \\
\mathrm{Al}\end{array}$ & & $\begin{array}{l}0.11 \\
0.41 \\
0.09 \\
0.006\end{array}$ & $\begin{array}{l}0.12 \\
0.39 \\
0.09 \\
0.005\end{array}$ & $\begin{array}{l}0.12 \\
0.45 \\
0.09 \\
0.006\end{array}$ & & & $\begin{array}{l}0.10 \\
0.21 \\
0.10\end{array}$ & $\begin{array}{l}0.13 \\
0.37 \\
0.09\end{array}$ & $\begin{array}{l}0.10 \\
0.40 \\
0.09\end{array}$ & $\begin{array}{l}0.11 \\
0.42 \\
0.10\end{array}$ & $\begin{array}{l}0.11 \\
0.42 \\
0.07\end{array}$ \\
\hline & $\begin{array}{c}\mathrm{Cr} \\
\mathrm{Mo} \\
\mathrm{V} \\
\mathrm{Al}\end{array}$ & & $\begin{array}{l}0.11 \\
0.41 \\
0.08 \\
0.004\end{array}$ & $\begin{array}{l}0.10 \\
0.37 \\
0.09 \\
0.006\end{array}$ & $\begin{array}{l}0.12 \\
0.42 \\
0.09 \\
0.004\end{array}$ & $\begin{array}{l}0.13 \\
0.45 \\
0.09 \\
0.005\end{array}$ & $\begin{array}{l}0.10 \\
0.42 \\
0.11\end{array}$ & $\begin{array}{l}0.11 \\
0.45 \\
0.11\end{array}$ & $\begin{array}{l}0.10 \\
0.41 \\
0.10\end{array}$ & $\begin{array}{l}0.11 \\
0.44 \\
0.10\end{array}$ & $\begin{array}{l}0.11 \\
0.45 \\
0.10\end{array}$ & $\begin{array}{l}0.09 \\
0.44 \\
0.11\end{array}$ \\
\hline & $\begin{array}{c}\mathrm{Cr} \\
\mathrm{Mo} \\
\mathrm{V} \\
\mathrm{Al}\end{array}$ & $\begin{array}{l}0.11 \\
0.40 \\
0.07 \\
0.008\end{array}$ & $\begin{array}{l}0.11 \\
0.38 \\
0.07 \\
0.008\end{array}$ & $\begin{array}{l}0.11 \\
0.36 \\
0.08 \\
0.008\end{array}$ & $\begin{array}{l}0.11 \\
0.40 \\
0.07 \\
0.006\end{array}$ & $\begin{array}{l}0.12 \\
0.39 \\
0.07 \\
0.008\end{array}$ & $\begin{array}{l}0.10 \\
0.43 \\
0.11\end{array}$ & $\begin{array}{l}0.10 \\
0.43 \\
0.11\end{array}$ & $\begin{array}{l}0.10 \\
0.45 \\
0.11\end{array}$ & $\begin{array}{l}0.10 \\
0.43 \\
0.11\end{array}$ & $\begin{array}{l}0.10 \\
0.43 \\
0.10\end{array}$ & $\begin{array}{l}0.09 \\
0.39 \\
0.11\end{array}$ \\
\hline & $\begin{array}{c}\mathrm{Cr} \\
\mathrm{Mo} \\
\mathrm{V} \\
\mathrm{Al}\end{array}$ & $\begin{array}{l}0.11 \\
0.40 \\
0.07 \\
0.010\end{array}$ & $\begin{array}{l}0.11 \\
0.38 \\
0.07 \\
0.007\end{array}$ & $\begin{array}{l}0.11 \\
0.38 \\
0.08 \\
0.008\end{array}$ & $\begin{array}{l}0.11 \\
0.39 \\
0.07 \\
0.009\end{array}$ & $\begin{array}{l}0.12 \\
0.38 \\
0.07 \\
0.007\end{array}$ & $\begin{array}{l}0.10 \\
0.43 \\
0.11\end{array}$ & $\begin{array}{l}0.10 \\
0.45 \\
0.11\end{array}$ & $\begin{array}{l}0.10 \\
0.43 \\
0.11\end{array}$ & $\begin{array}{l}0.11 \\
0.43 \\
0.11\end{array}$ & $\begin{array}{l}0.10 \\
0.42 \\
0.10\end{array}$ & $\begin{array}{l}0.10 \\
0.44 \\
0.09\end{array}$ \\
\hline & $\begin{array}{c}\mathrm{Cr} \\
\mathrm{Mo} \\
\mathrm{V} \\
\mathrm{Al}\end{array}$ & $\begin{array}{l}0.11 \\
0.39 \\
0.08 \\
0.008\end{array}$ & $\begin{array}{l}0.11 \\
0.43 \\
0.07 \\
0.007\end{array}$ & $\begin{array}{l}0.11 \\
0.38 \\
0.07 \\
0.008\end{array}$ & $\begin{array}{l}0.11 \\
0.38 \\
0.07 \\
0.010\end{array}$ & $\begin{array}{l}0.11 \\
0.40 \\
0.07 \\
0.006\end{array}$ & $\begin{array}{l}0.10 \\
0.42 \\
0.11\end{array}$ & $\begin{array}{l}0.10 \\
0.42 \\
0.11\end{array}$ & $\begin{array}{l}0.10 \\
0.45 \\
0.10\end{array}$ & $\begin{array}{l}0.10 \\
0.47 \\
0.11\end{array}$ & $\begin{array}{l}0.11 \\
0.42 \\
0.10\end{array}$ & $\begin{array}{l}0.09 \\
0.43 \\
0.10\end{array}$ \\
\hline 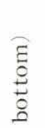 & $\begin{array}{c}\mathrm{Cr} \\
\mathrm{Mo} \\
\mathrm{V} \\
\mathrm{Al}\end{array}$ & $\begin{array}{l}0.11 \\
0.40 \\
0.07 \\
0.008\end{array}$ & $\begin{array}{l}0.12 \\
0.43 \\
0.07 \\
0.008\end{array}$ & $\begin{array}{l}0.13 \\
0.07 \\
0.07 \\
0.007\end{array}$ & $\begin{array}{l}0.11 \\
0.41 \\
0.07 \\
0.008\end{array}$ & $\begin{array}{l}0.11 \\
0.41 \\
0.07 \\
0.011\end{array}$ & $\begin{array}{l}0.10 \\
0.43 \\
0.11\end{array}$ & $\begin{array}{l}0.10 \\
0.42 \\
0.11\end{array}$ & $\begin{array}{l}0.11 \\
0.43 \\
0.11\end{array}$ & $\begin{array}{l}0.11 \\
0.45 \\
0.12\end{array}$ & $\begin{array}{l}0.11 \\
0.42 \\
0.11\end{array}$ & $\begin{array}{l}0.09 \\
0.39 \\
0.09\end{array}$ \\
\hline $\begin{array}{l}\stackrel{8}{8} \\
\stackrel{2}{8}\end{array}$ & $\begin{array}{c}\mathrm{Cr} \\
\mathrm{Mo} \\
\mathrm{V} \\
\mathrm{Al}\end{array}$ & $\begin{array}{l}0.12 \\
0.40 \\
0.07 \\
0.008\end{array}$ & $\begin{array}{l}0.12 \\
0.43 \\
0.07 \\
0.007\end{array}$ & $\begin{array}{l}0.11 \\
0.37 \\
0.07 \\
0.007\end{array}$ & $\begin{array}{l}0.11 \\
0.38 \\
0.07 \\
0.005\end{array}$ & $\begin{array}{l}0.11 \\
0.41 \\
0.07 \\
0.011\end{array}$ & $\begin{array}{l}0.10 \\
0.42 \\
0.11\end{array}$ & $\begin{array}{l}0.10 \\
0.43 \\
0.11\end{array}$ & $\begin{array}{l}0.10 \\
0.42 \\
0.11\end{array}$ & $\begin{array}{l}0.10 \\
0.43 \\
0.10\end{array}$ & $\begin{array}{l}0.10 \\
0.41 \\
0.09\end{array}$ & $\begin{array}{l}0.10 \\
0.41 \\
0.09\end{array}$ \\
\hline 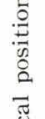 & $\begin{array}{c}\mathrm{Cr} \\
\mathrm{Mo} \\
\mathrm{V} \\
\mathrm{A} 1\end{array}$ & $\begin{array}{l}0.11 \\
0.39 \\
0.07 \\
0.008\end{array}$ & $\begin{array}{l}0.11 \\
0.40 \\
0.08 \\
0.009\end{array}$ & $\begin{array}{l}0.11 \\
0.38 \\
0.07 \\
0.010\end{array}$ & $\begin{array}{l}0.13 \\
0.39 \\
0.07 \\
0.010\end{array}$ & $\begin{array}{l}0.11 \\
0.39 \\
0.07 \\
0.010\end{array}$ & $\begin{array}{l}0.10 \\
0.43 \\
0.11\end{array}$ & $\begin{array}{l}0.10 \\
0.43 \\
0.11\end{array}$ & $\begin{array}{l}0.11 \\
0.43 \\
0.11\end{array}$ & $\begin{array}{l}0.10 \\
0.39 \\
0.09\end{array}$ & $\begin{array}{l}0.10 \\
0.38 \\
0.10\end{array}$ & $\begin{array}{l}0.09 \\
0.39 \\
0.09\end{array}$ \\
\hline 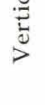 & $\begin{array}{c}\mathrm{Cr} \\
\mathrm{Mo} \\
\mathrm{V} \\
\mathrm{Al}\end{array}$ & $\begin{array}{l}0.11 \\
0.44 \\
0.07 \\
0.008\end{array}$ & $\begin{array}{l}0.11 \\
0.40 \\
0.09 \\
0.008\end{array}$ & $\begin{array}{l}0.11 \\
0.42 \\
0.08 \\
0.008\end{array}$ & $\begin{array}{l}0.09 \\
0.40 \\
0.07 \\
0.008\end{array}$ & $\begin{array}{l}0.12 \\
0.40 \\
0.08 \\
0.010\end{array}$ & $\begin{array}{l}0.10 \\
0.42 \\
0.11\end{array}$ & $\begin{array}{l}0.10 \\
0.42 \\
0.11\end{array}$ & $\begin{array}{l}0.10 \\
0.46 \\
0.10\end{array}$ & $\begin{array}{l}0.10 \\
0.39 \\
0.10\end{array}$ & $\begin{array}{l}0.10 \\
0.37 \\
0.09\end{array}$ & $\begin{array}{l}0.10 \\
0.38 \\
0.09\end{array}$ \\
\hline & $\begin{array}{c}\mathrm{Cr} \\
\mathrm{Mo} \\
\mathrm{V} \\
\mathrm{A} 1\end{array}$ & $\begin{array}{l}0.11 \\
0.42 \\
0.07 \\
0.009\end{array}$ & $\begin{array}{l}0.12 \\
0.41 \\
0.08 \\
0.007\end{array}$ & $\begin{array}{l}0.12 \\
0.42 \\
0.08 \\
0.007\end{array}$ & $\begin{array}{l}0.11 \\
0.40 \\
0.07 \\
0.008\end{array}$ & $\begin{array}{l}0.10 \\
0.40 \\
0.07 \\
0.006\end{array}$ & $\begin{array}{l}0.10 \\
0.43 \\
0.11\end{array}$ & $\begin{array}{l}0.10 \\
0.43 \\
0.11\end{array}$ & $\begin{array}{l}0.10 \\
0.43 \\
0.11\end{array}$ & $\begin{array}{l}0.10 \\
0.38 \\
0.09\end{array}$ & $\begin{array}{l}0.10 \\
0.37 \\
0.10\end{array}$ & $\begin{array}{l}0.10 \\
0.40 \\
0.09\end{array}$ \\
\hline & $\begin{array}{c}\mathrm{Cr} \\
\mathrm{Mo} \\
\mathrm{V} \\
\mathrm{Al}\end{array}$ & $\begin{array}{l}0.11 \\
0.42 \\
0.08 \\
0.010\end{array}$ & $\begin{array}{l}0.41 \\
0.07 \\
0.007\end{array}$ & $\begin{array}{l}0.10 \\
0.39 \\
0.08 \\
0.008\end{array}$ & $\begin{array}{l}0.11 \\
0.37 \\
0.08 \\
0.008\end{array}$ & $\begin{array}{l}0.11 \\
0.40 \\
0.07 \\
0.009\end{array}$ & $\begin{array}{l}0.10 \\
0.42 \\
0.11\end{array}$ & $\begin{array}{l}0.10 \\
0.42 \\
0.11\end{array}$ & $\begin{array}{l}0.10 \\
0.42 \\
0.11\end{array}$ & $\begin{array}{l}0.10 \\
0.41 \\
0.10\end{array}$ & $\begin{array}{l}0.10 \\
0.42 \\
0.10\end{array}$ & $\begin{array}{l}0.11 \\
0.39 \\
0.09\end{array}$ \\
\hline & $\begin{array}{c}\mathrm{Cr} \\
\mathrm{Mo} \\
\mathrm{V} \\
\mathrm{Al}\end{array}$ & & & $\begin{array}{l}0.12 \\
0.42 \\
0.08 \\
0.010\end{array}$ & $\begin{array}{l}0.12 \\
0.39 \\
0.08 \\
0.009\end{array}$ & $\begin{array}{l}0.11 \\
0.38 \\
0.08 \\
0.008\end{array}$ & $\begin{array}{l}0.10 \\
0.42 \\
0.11\end{array}$ & & & $\begin{array}{l}0.09 \\
0.42 \\
0.09\end{array}$ & $\begin{array}{l}0.10 \\
0.40 \\
0.10\end{array}$ & $\begin{array}{l}0.09 \\
0.40 \\
0.09\end{array}$ \\
\hline & $\begin{array}{c}\mathrm{Cr} \\
\mathrm{Mo} \\
\mathrm{V} \\
\mathrm{Al}\end{array}$ & & & & & & & & & $\begin{array}{l}0.09 \\
0.43 \\
0.11\end{array}$ & $\begin{array}{l}0.09 \\
0.43 \\
0.11\end{array}$ & $\begin{array}{l}0.09 \\
0.41 \\
0.09\end{array}$ \\
\hline & $\begin{array}{c}\mathrm{Cr} \\
\mathrm{Mo} \\
\mathrm{V} \\
\mathrm{Al}\end{array}$ & & & & & & & & & $\begin{array}{l}0.09 \\
0.43 \\
0.11\end{array}$ & $\begin{array}{l}0.10 \\
0.43 \\
0.11\end{array}$ & $\begin{array}{l}0.08 \\
0.43 \\
0.12\end{array}$ \\
\hline & $\begin{array}{c}\mathrm{Cr} \\
\mathrm{Mo} \\
\mathrm{V} \\
\mathrm{Al}\end{array}$ & & & & & & & & & $\begin{array}{l}0.02 \\
0.40 \\
0.11\end{array}$ & $\begin{array}{l}0.09 \\
0.43 \\
0.11\end{array}$ & $\begin{array}{l}0.09 \\
0.43 \\
0.12\end{array}$ \\
\hline
\end{tabular}


now described, with particular reference to the 75 -t ingot.

The distribution of carbon and sulphur along the longitudinal section is shown in Fig. 5 in comparison with an air-cast ingot. As seen from the figure, it is of interest that the axial segregation in the core zone is notably reduced in a vacuumcast ingot. This reduction could not be exactly discussed because of the differences of ingot shape, feeder thermal insulation, etc., but the boiling state at a certain depth in molten steel during vacuum casting possibly should be considered as one of the reasons. This will be a problem of further study.

Distribution of elements other than those shown in Fig. 5 has quite the same tendency as in Tables 2 and 3 . The tendency for the 9 -t and 25-t ingots is also the same.

\section{Distribution of Various Gases}

Comparing with the air-cast ingot the distribution of hydrogen in the 75-t vacuum-cast ingot is shown in the top rows of Fig. 6. The distribution is more uniform and the mean value is lowered to 1.5 p.p.m. in the vacuum-cast ingot. The same level of 1.5 p.p.m. holds also for 9 -t and 25-t ingots, a figure which exceeds the case of a steam-ejector evacuation by about 0.5 p.p.m.

In Table 4 is shown the distribution of oxygen and nitrogen in 75-t ingots, vacuum and air-cast. The oxygen in a vacuum ingot has a rather high figure at the outer periphery zone but lowers towards the inner zone. The distribution of oxygen will be discussed again in connection with inclusions. The nitrogen shows very little segregation, its mean content remaining nearly unchanged.

\section{Sand and Nonmetallic Inclusions}

i. $\mathrm{SiO}$, and $\mathrm{Al}_{2} \mathrm{O}_{3}$

Distribution of $\mathrm{SiO}_{2}$ and $\mathrm{Al}_{2} \mathrm{O}_{3}$ in the 75 - $\mathrm{t}$ vacuumcast ingot is shown in Fig. 6. Main component of oxide inclusions is $\mathrm{Al}_{2} \mathrm{O}_{3}$ which has a higher value for the outer fast-solidified zone and a lower value for the core zone where rate of solidification is slow to provide enough chance for floatation. On the contrary, $\mathrm{SiO}_{2}$ has a region of somewhat higher value, which is presumably formed at the time of solidification or at a period nearest to it. At any rate the absolute value of the oxide content is low, proving that the prevention of oxidation of tapped steel and the reduction of oxygen with carbon deoxidation at low pressure are very efficient. This presumably endorses also the low value of oxygen in Table 4.

ii. Microscopic Examination of Nonmetallic Inclusions

The result of examination is shown in Table 5 . It is almost free from silicates, but sulphide in- clusions are on the level of ordinary ingots. There are very few oxides, coinciding with the results of oxygen analysis and acid-separation analysis of the oxides.

\section{Summary and Conclusions}

Air-melted or vacuum-cast ingots of 9-t, 25-t and 75-t were split and investigated in comparison with air-cast ingots of the similar size. Effects of vacuum casting upon the internal quality of large ingots were found as follows:

(1) In these ingots, cast at a range of 5-8 Torr, gases and oxide inclusions are notably reduced, reconfirming the published results of other authors.

(2) Macro-segregation of chemical components is decreased considerably.

(3) Local segregations, i.e. V- or inverse-V segregations, are much improved. Above all, V-segregations are remarkably reduced.

(4) Cavities and loose structures accompanied by

Table 4. Distribution of $\mathrm{O}_{2}$ and $\mathrm{N}_{2}$ in 75-ton ingots $(\mathrm{As}$ for the positions of sampling refer to Fig. 5 .

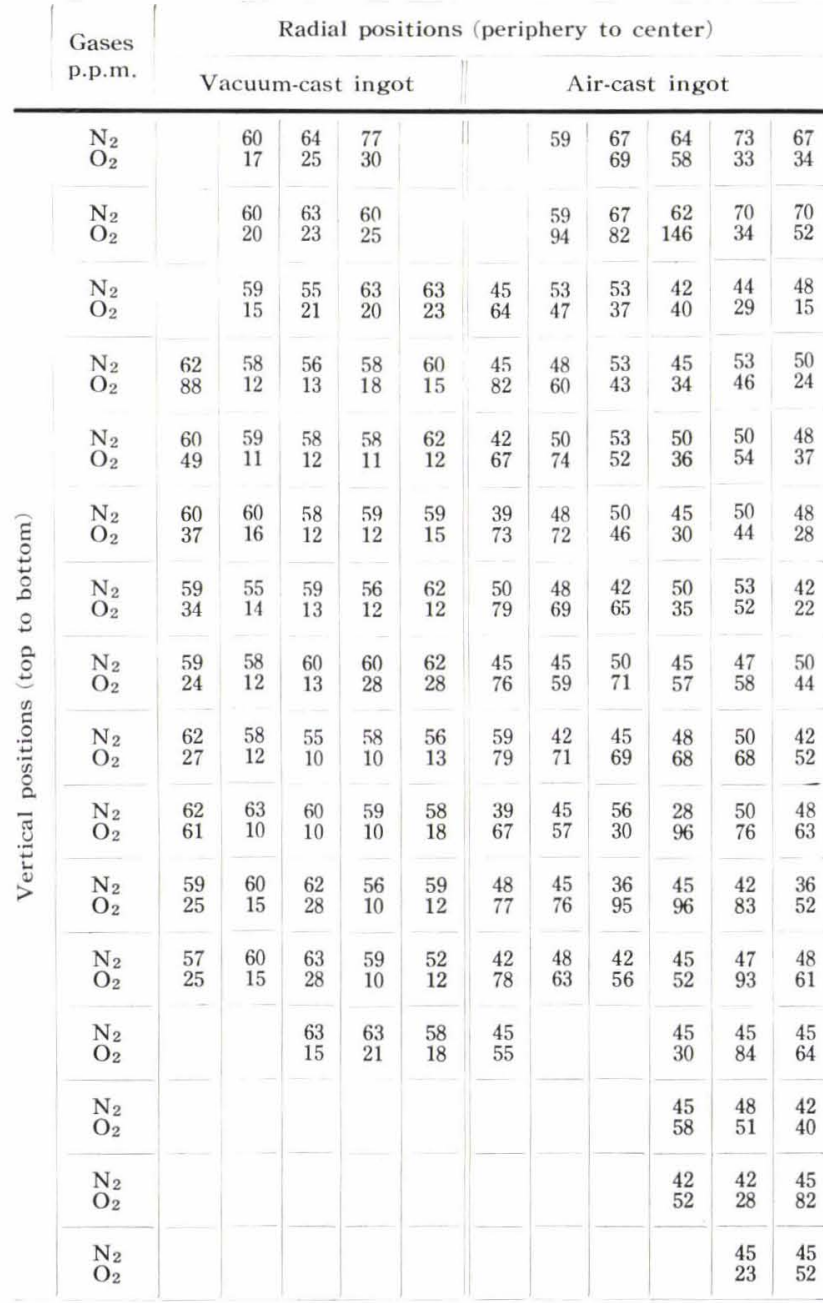


Table 5. Distribution of microscopic inclusions (As for the positions of sampling refer to Fig. 5 .

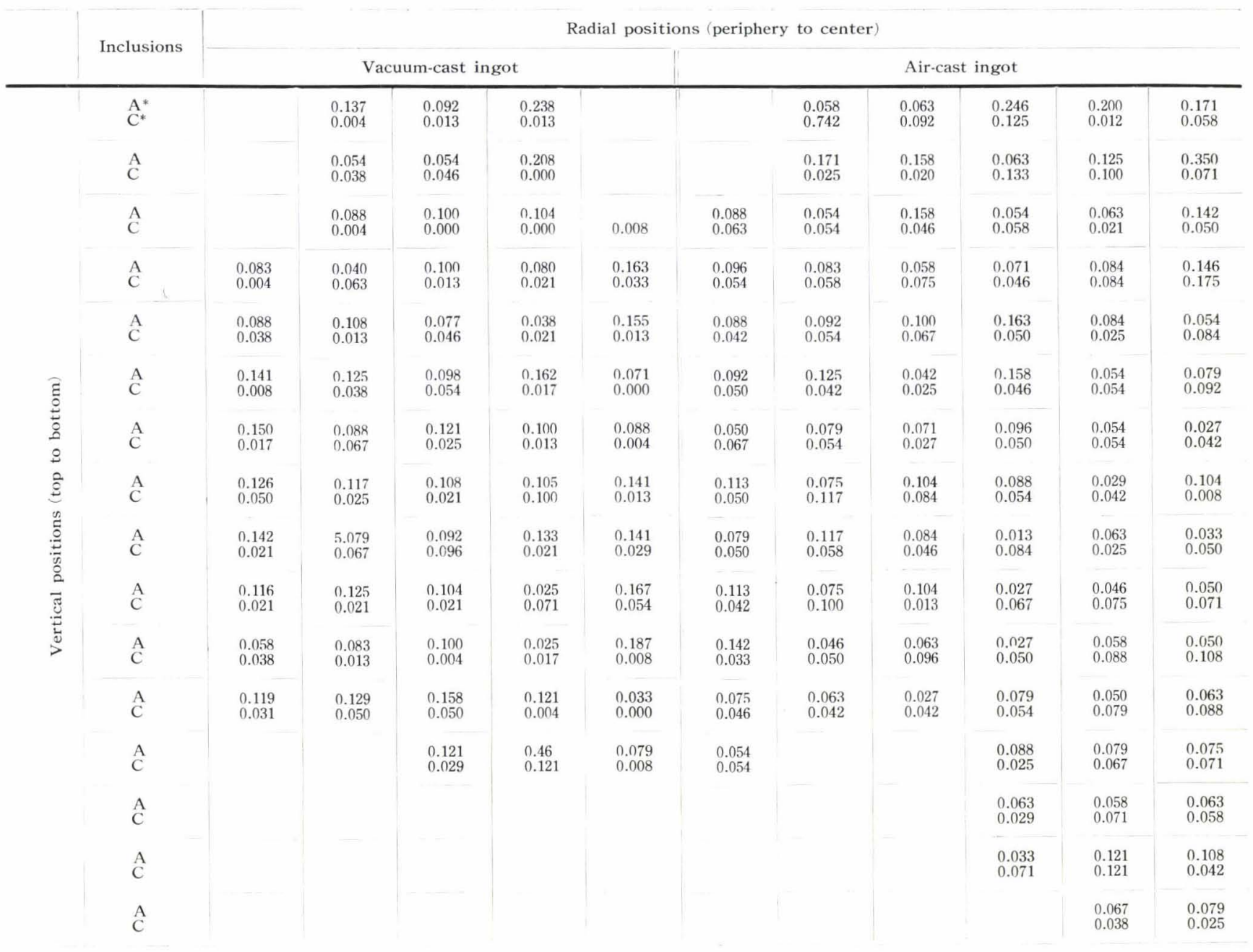

* A: Silicates and sulphides.

* C: Oxides.

these local segregations are reduced remarkably. The inverse- $V$ segregates show, when revealed by macro-etching, little heterogeneity against the surrounding background. This phenomenon is important as it suggests some effects of retained gases on the formation of local segregations.

It should be noted that this paper concerns the internal structure of vacuum-cast ingots manufactured by Muroran Plant of Japan Steel Works, Ltd. The improvement in recent products made from vacuum-ingots is evident enough in this plant. Then, these findings on the internal structure of vacuum-cast ingots can be said to be of general interest.

In concluding this paper, the authors express their thanks to the late Takamitsu Minakawa, exmanaging director and general manager of Muroran Plant, the Japan Steel Works, Ltd. and to
Katsutoshi Isaji, director and general manager of the plant, for permission to publish this paper. Gratitude is also due to Dr. Hideo Shimoda, Dr. Shigeya Maekawa and $\mathrm{Mr}$. Tsuneo Ikemi for their invaluable guidance in this investigation.

\section{REFERENCE}

1) A. Tix: Stahl u. Eisen, 76 (1956), S. 61, and other papers of similar content. 